\title{
THE PUBLIC AUTHORITY: SOME LEGAL AND PRACTICAL ASPECTS
}

\author{
BY PETER R. NEHEMKIS, JR. $\dagger$
}

The PUBLIC Authority may be described as a special public corporation whose obligations are payable solely from its revenues or property, or both, without recourse to taxes and special assessments. ${ }^{1}$ Although the authority has long occupied a significant place among Anglo-American governmental units, ${ }^{2}$ it is doubtful whether its advantages have been fully appreciated or even understood. Yet these advantages are many. Since the authority depends for economic survival upon its own earnings rather than upon legislative largess, a greater degree of operating efficiency necessarily results. Where constitutional or statutory debt limits preclude further borrowing, the authority provides a municipality with a convenient credit base without exceeding the debt limit or placing an undesired burden upon the taxpayer. And, functioning as a corporate entity, the authority not only permits speed and flexibility in administration but also places legal liability where it belongs - on the enterprise itself.

\section{Incorporation, Structure, and Powers}

The public authority in this country has, in general, been organized in one of three ways: (a) by special act of the State legislature establishing a specific corporate instrumentality for effecting a particular purpose, viz., construction and operation of a bridge, tunnel, health resort, produce market; (b) by a permissive general statute authorizing the incorporation of an improvement authority in areas of a given population to accomplish a variety of purposes; (c) by a permissive general statute enabling the electorate of a defined geographical area to incorporate as a public corporation by vote at a special election.

Incorporation by Special Act. The legislature of the State of New York has adhered to the method of incorporating specific authorities

TStaff of the General Counsel, Public Utilities Division, Securities Exchange Commission.

The author gratefully acknowledges his deep appreciation and thanks to J. Anthony Panuch of the New York Bar for his painstaking and critical reading of the manuscript.

1. While the authority is in many respects similar to the improvement or special assessment district, the two may be distinguished by their financing methods. The authority depends solely on its revenues to meet obligations while district obligations are paid either by special assessments on the property benefitted or by exercise of the general taxing power. See Williams \& Nehemkis, Municipal Improvements As Affected By Constitutional Debt Limitations (1937) 37 CoL. L. REv. 177, at 203, n. 115.

2. Id. at 202 , n. 111. On the Port of London Authority, which has been the pattern of American authorities, see OwEN, The PoRT of London (1927). 
to carry out particular purposes. Including the Port of New York Authority there are some thirty-one authorities in the State engaged in the following activities: ${ }^{3}$ bridge and tunnels, parks," marketing, public utilities, ${ }^{7}$ housing, ${ }^{8}$ and a miscellaneous category embracing a health institution, ${ }^{9}$ a natural history planetarium, ${ }^{10}$ an industrial exhibit, ${ }^{11}$ a war memorial, ${ }^{12}$ and a sewerage authority. ${ }^{13}$ Analysis and comment upon the procedure followed in this state illumines similar practices elsewhere. ${ }^{14}$

New York follows, with minor exceptions, a uniform pattern in the creation of its various authorities. They are designated "public benefit corporations," bodies corporate and politic, ${ }^{15}$ and endowed with either a limited or perpetual corporate existence. ${ }^{10}$ Membership to the directorate is appointive for fixed periods, the power of appointment and the corresponding power of removal being vested in either the governor, the mayor of a city, or some other governing body. The directors or trustees of the authorities receive no stipulated compensation other than reasonable expenses. Included among the powers of the corporate authority are the right to sue and be sued, to use a corporate seal, to hold and acquire real and personal property, to make by-laws for the management

3. See Williams \& Nehemkis, supra note 1 , at $201, \mathrm{n}$. 119; see also TuE Pons of New York Authority: A Mlonograph (1936).

4. See, e.g., New York State Bridge Authority (N. Y. Laws 1932, c. 548, as amended by N. Y. Laws 1933, c. 67).

5. See, e.g., Pelham-Port Chester Parkway Authority (N. Y. Laws 1933, c. 6S).

6. Lower Hudson Regional Market Authority (N. Y. Laws 1933, c. 231, as amended by N. Y. Laws 1935, c 844).

7. Power Authority of the State of New York (N. Y. Laws 1931, c. 772, as amended by N. Y. Laws 1933, c. 448 ).

8. N. Y. Laws 1934, c. 4 as amended by N. Y. Laws 1935, c. 310.

9. Saratoga Springs Authority (N. Y. Laws 1933, c. 208).

10. The American Museum of Natural History Planetarium Authority (N. Y. Laws 1933, c 214, as amended by N. Y. Laws 1933, c. 816, 817).

11. Industrial Exhibit Authority (N. Y. Laws 1933, c. 246, as amended by $\lambda$. Y. Laws 1934, c. 304).

12. New York State World War Mfemorial Authority (N. Y. Laws 1934, c. 819).

13. Buffalo Sewer Authority (N. Y. Laws 1935, c. 349).

14. See, e.g., California Toll Bridge Authority, Cal. Stat. 1929, c. 763; Panama - City Port Authority, Fla. Spec. Acts 1935, c. 17643; Mackinac Bridge Authority, MLich. Pub. Acts Extra Sess. 1934, No. 35; Hackensack River Sewerage Authority, N. J. Laws 1933, c. 373.

15. This designation is designed to establish the authorities as state instrumentalities and thereby achieve tax exemption for the obligations issued. See p. $26 \mathrm{et}$ seq., infro.

16. The marketing [note 6 supra] and public utility [note 7 supra] authorities have been endowed with perpetual existence. Limited corporate existence obtains, for example, in the case of the Saratoga Springs Authority [note 9 sipra], Jones Beach State Parl:way Authority, N. Y. Laws 1933, c. 70, and the New York State Bridge Authority [note 4 supra]. In the absence of an express limitation on duration, a "termination" section is usually provided, vis., "whenever all of the bonds issued by the authority shall have been redeemed and/or cancelled, the authority shall cease to exist * *." 
and regulation of its affairs, to enter into contracts, and, in certain instances, to exercise eminent domain proceedings. ${ }^{17}$ The authority may incur debt and issue its own bonds, which may be sold at public or private sale, although the total issue is not permitted to exceed a fixed amount. ${ }^{18}$ Each act creating an authority expressly immunizes the city, county or state governments from liability on the authority's debt, ${ }^{10}$ and the bonds of the authority are specifically exempted from state taxation. ${ }^{20}$ Usually a mortgage on enterprise property is not specifically authorized, ${ }^{21}$ the security device in New York being an hypothecation of enterprise revenues or tolls, or both.

The terms of the several New York acts empower an authority to pledge all of its tolls and revenues over and above operating expenses for principal of and interest on bonds issued by the authority, to covenant with the bondholders to charge such fees and tolls as shall be sufficient to provide revenue for debt service, to enter into agreements with respect to restrictions covering the disposition of toll and revenue funds, to establish sinking funds and provide for the payment of a certain proportion of revenues to such funds, to enter into agreements to create other reserve funds and to covenant with the bondholders governing the management and investment of such funds as well as sinking funds, to enter into agreements respecting restrictions upon future issues of bonds, and to contract with bondholders as to the uses to which the facilities of the authority may be employed. ${ }^{22}$

17. E.g., Henry Hudson Parkway Authority [note 5 supra] ; Lower Hudson Regional Market Authority [note 6 supra].

18. Thus, the New York City Tunnel Authority may become obligated for an amount up to $\$ 200,000,000$; the Saratoga Springs Authority may not exceed a debt of $\$ 5,000,000$.

19. The statutory provisions of several acts suggest that the State might assume liability in the event of default. See e.g., the Jones Beach Parkway Authority Act [note 16 supra] $\S 6(4)$; see also, Williamsburgh Savings Bank v. State, 243 N. Y. 231, 153 N. E. 58 (1926).

20. The New York enactments, being contractual in character and presumably made for a consideration received or supposed to be received by the State, would appear to be outside the scope of the State constitutional provision [Article VIII, $\S 1$, Const. 1846] empowering the State legislature to alter corporate charters. In other words, the exemption is not a mere privilege.

21. But in the legislative acts of two authorities, [Bethpage Park Authority, N. Y. Laws 1933, c. 801, and Buffalo \& Fort Erie Public Bridge Authority, N. Y. Laws 1933, c. 824], a mortgage on enterprise property is permitted.

22. The practical application of the foregoing pledge provisions may be seen from the resolution adopted by the Buffalo Sewer Authority, June 1, 1936, authorizing an issue of $\$ 8,250,000$ of Authority bonds. The resolution is tantamount to a trust indenture and contains the familiar covenants and provisions associated with the indenture instrument, viz., authorization, terms, execution, registration and issue of bonds, form of bonds, etc., particular covenants of the Authority, and provisions concerning the Fiscal Agent. Compare this with usual provision "Concerning the Trustee." 
In addition to the foregoing provisions, ${ }^{23}$ the New York legislative draftsmen have inserted in certain of the acts ${ }^{24}$ restrictive covenants against future competition by the local or state government with the facilities of the existing authority. For example, in the Jones Beach State Parkway Authority Act it is provided that:

"The State of New York does pledge to and agree with the holders of any bonds that the state will not authorize the construction or maintenance of any parkway, causeway, bridge, tunnel, street, road, highway or other connection for vehicular traffic, which will be competitive with Jones Beach parkway * * ."

A covenant has also been included in virtually all of the New York acts to the effect that the State will not limit or alter the rights vested in the authority to collect such charges or tolls as are required to produce sufficient revenue for maintenance and operation, or in any way impair the rights and remedies of the bondholders "until the bonds, together with interest thereon, with interest on any unpaid installments of principal and interest, and all costs and expenses in connection with any actions or proceedings, by or on behalf of the bondholders, are fully met and discharged." 26

Permissive General Statute. The legislation enacted by the states of Florida and Pennsylvania serves to illustrate the second type of authority incorporation. The Florida Act ${ }^{27}$ is brief. Under its terms the Board of County Commissioners may by resolution request the Governor to appoint a Development Authority for the County. ${ }^{23}$ An authority when so formed by appointment of the Governor is deemed a public corporation of the state in perpetuity, its corporate powers are in substance similar to those prevailing under the New York legislation, and its obligations,

23. For the remedies reserved to bondholders, see infra, p. $24 \mathrm{ct} \mathrm{seq}$.

24. See, e.g., New York State Bridge Authority, [note 4 supra]; Lower Hudson Regional Market Authority, [note 6 supra].

25. Where the legislative act leaves undefined the question of what constitutes competition (assuming that ultimate definition is possible) future litigation would seem inevitable. The act establishing the Jones Beach Parkway Authority attempts to meet the issue by particularizing the nature of a competitive facility. N. Y. Laws 1933, c. 70, \$10. See also California Toll Bridge Authority Act, Cal. St3t. 1929, c. 763.

26. Jones Beach State Parkway Authority, N. Y. Laws 1933, c. 70, $\$ 10$.

27. Fla. Laws 1935, c. 16974. See also, e.g., ALA. Code Axis. (Alichie, Supp. 1936) $\$ 1422$ (improvement authorities to furnish water, sewerage, telephone, gas, electric, light and power service).

28. The purposes which may be undertaken by a Development Authority are the construction and operation of toll bridges and highways, public parks, playgrounds, amusement places, fish ponds and hatcheries, school houses, court houses, community centers, and club houses, and rural housing development. Id. at $\$ 7$. Although the statute is general in its terms, it is in effect tantamount to a specinl act, since it may be employed only by counties having a population between 15,500 and 16,000 in the last census. 
which may be issued either in the form of mortgage bonds or revenue bonds, are expressly made its own debt.

Under the Pennsylvania legislation, authorities may be established by both counties of the second class ${ }^{29}$ and municipalities, ${ }^{30}$ with a similar incorporation procedure provided for each. The municipal officials or county commissioners may signify their intention of forming an authority by appropriate resolution and advertisement of the resolution, and by filing articles of incorporation with the Secretary of the Commonwealth. After they have been approved by the Secretary, the articles constitute the charter of the authority. ${ }^{31}$ Membership to the directorate is by appointment of the county officials or municipal officials. Unlike New York, the Pennsylvania statutes permit directors to receive compensation. No remedy is provided expressly for bondholders in the event of default by county authorities, ${ }^{32}$ but the Municipal Authorities Act specifically contemplates the use of a trust indenture and provides remedies similar to those used in New York. ${ }^{33}$ Apart from a novel provision stipulating that upon termination of the authority its property vests in the municipality, the Pennsylvania and New York legislation are substantially alike.

Permissive General Statute by Vote of Electorate. The "Improvement Authority" Act of South Dakota is typical of this method of incorporation. ${ }^{34}$ Under this Act the electorate of any geographical area within the state coterminous with the boundaries of a city or town containing a population of not less than five hundred inhabitants may, upon filing a petition to the local governing body, request the submission to a vote at a general election of the question of whether there shall be incorporated

29. Pa. Stat. AnN. (Purdon, 1936) tit. 16, $\$ \$ 4160-4161$. These counties may create authorities to construct, maintain, and operate bridges, tunnels, streets, highways, traffic circles, airports, hangars, parkways, recreation grounds, public parks, swimming pools, lakes and dams.

30. Pa. Stat. Ans. (Purdon, 1936) tit. 53, $\$ 2900$ (i). Municipalities may engage in projects similar to those permitted second class counties [see note 29 , supra] along with low cost housing projects, sewer systems, hospitals and subways.

31. Incorporation by certificate has distinct limitations as compared with the method of incorporation by special act. For one thing, a general tax law repealing tax exemptions is generally held not to repeal a special act containing tax exemptions in the absence of an express repealer. For a recent expression of judicial opinion, see Pcople ex rel. Cooper Union v. Sexton et al., 247 App. Div. 371, 287 N. Y. S. 440 (1st Dep't 1936). Incorporation by special act buttresses the attempt to "freeze" state tax exemptions.

32. Since the statute contemplates the execution of a mortgage, detailed security provisions would appear to be unnecessary. In fact, the trust indenture entered into by the Allegheny County Authority, which was incorporated pursuant to this act, and contained in Article VIII the usual remedies of the trustee and bondholders including the right of entry upon and operation of the authority enterprise. See Tranter v. Allegheny County Authority, 316 Pa. 65, 173 Atl. 289 (1934).

33. Pa. Stat. Ann. (Purdon, 1936), tit. 53, §2900(j).

34. S. D. Laws 1935 , c. 73. 
an improvement authority. An authority so incorporated may engage in any or all of the following activities: water, sewerage, gas or electric heat, light or power service, commodities or facilities. ${ }^{35}$ Upon incorporation, the improvement authority is deemed a public corporation in perpetuity, with a directorate consisting of three members, designated a "board of trustees" 36 and appointed by the local governing body to serve without compensation. A power of removal is vested in the Governor. The plenary powers conferred on the trustees, the immunization of the state and municipality from authority debts, and the rights and remedies given to bondholders, are substantially similar to the powers granted under the New York Acts.

\section{Constitutronal Problears}

Delegation of Powers. That the States have power to establish public authorities as agencies of the State government would appear to be no longer open to question. ${ }^{37}$ Nevertheless, each new venture seems fated to run the gauntlet of constitutional scrutiny by the State courts. Thus, only recently, in Tranter v. Allegheny County Authority ${ }^{35}$ the Pennsylvania enabling act was attacked on the ground that, by empowering the county commissioners to take the steps necessary to obtain the charter for the Authority, ${ }^{39}$ there had been an unlawful delegation of legislative power. The Supreme Court of Pennsylvania held, however, in accordance with the usual rule, that the exercise of a specific privilege conferred by the Legislature was not an improper delegation. ${ }^{10}$

Trespass on Home Rule. A more difficult question presents itself in considering whether authority legislation encroaches upon municipal home rule laws and is "special" or "local" either in its terms or effect. On

35. Id. at $\S 3$.

36. Id. at $\$ 15$.

37. See County of Mfobile v. Kimball, 102 U. S. 691 (18S0); Gyynor v. Marohn, 268 N. Y. 417,198 N. E. 13 (1935); see generally Freunn, America: Anunsistmutrie LAw (1923) 118-124; Berle, The Expansion of American Administratice Lote (1917) 30 HARv. L. REv. 430.

38. $316 \mathrm{~Pa}$ 65, 173 Atl. 289 (1934). See also, Kelley v. Earle, 190 Atl. 140 (Pa. 1937) overruling Kelley v. Earle, $320 \mathrm{~Pa} .449,182$ Atl. 501 (1936), (1937) 85 U. PA. I. REv. 518, which had held the Pennsylvania General State Authority Act unconstitutional.

39. See p. 18, supra,

40. It was also urged by the taxpayer that the act was in conflict with the constitutional prohibition (Art. 9, $\$ 7$ ) against the loan of credit by any local unit of government to a private corporation. The argument was summarily dismissed. Trantner $r$. Allegheny County Authority, $316 \mathrm{~Pa} .65,80,173$ Atl. 289, 296 (1934). The identical issue was raised and dismissed in the following recent cases: Gaynor v. Marohn, 263 N. Y. 417, 198 N. E. 13 (1935) ; Robertson v. Zimmermann, 268 N.Y. 52, 196 N.E. 740 (1935). 
an issue involving this particular type of legislative trespass, the protagonists of Home Rule are prone to "confuse its objective of making popular government work, with the idea of local self-government." 11 The courts have not been free from this influence. The precise point at which the interest of the locality leaves off and that of the State begins lies in a penumbral zone. If a prohibition against special legislation interferes with the public necessity for electric light systems, transit facilities, power plants, bridges, and the like, sooner or later the courts are driven to the expediency of whittling away constitutional or statutory restraints.

The judicial experience of New York State throws the problem into bold relief. The Legislature in $1935^{42}$ created a public benefit corporation, the Buffalo Sewer Authority, to deal with sewerage and sanitary matters affecting the City of Buffalo and its contiguous territory. The act was promptly challenged in a taxpayer's suit in Robertson v. Zimmermann ${ }^{43}$ upon the ground, among others, that by transferring to the jurisdiction and control of the Authority the existing sewer system of the city, the Home Rule Amendment ${ }^{44}$ of the State was nullified. The Court of Appeals had already driven a wedge in the previously established test as to whether a law was "special or local" by ruling that inquiry was not restricted to an examination of whether an act was general or local "in its terms", the basic inquiry being directed to the question whether the act was general or local "in its effect." ${ }^{45}$ The process had been completed in a later case when Judge Cardozo pronounced the proper test to be

" *** that if the subject be in a substantial degree a matter of State concern, the Legislature may act, though intermingled with it are the concerns of the locality." 46

Under the circumstances, the Court of Appeals did not hesitate, therefore, in holding in the Robertson case ${ }^{47}$ that although the act there in question did interfere with the control by the City of Buffalo of its sewerage system, it was, nevertheless, neither "special or local" in its terms or effect.

41. McGoldrick, Law and Practice of Municipal Home Rule (1933) 3. See, also, Weiner, Municipal Home Rule in New York, (1937) 37 CoL. L. Rev. 557.

42. N. Y. Laws, 1935 , c. 349. See Williams \& Nehemkis, op. cit. supra note 1 , at 206, for a further treatment of this Authority.

43. 268 N. Y. 52, 196 N. E. 740 (1935).

44. N. Y. Const. 1894, art. XII, §2; N. Y. Laws 1923, p. 1765. See Weiner, loc. cit. supra note 41 .

45. Matter of Mayor of City of New York (Elm St.), 246 N. Y. 72, 76, 158 N. E. 24,26 (1927).

46. Adler v. Deegan, 251 N. Y. $467,491,167$ N. E. 705, 714 (1929) ; cf. Admiral Realty Co. v. City of New York, 206 N. Y. 110, 99 N. E. 241 (1912) ; Matter of McAneny v. Board of Estimate and Apportionment, 232 N. Y. 377, 134 N. E. 187 (1922).

47. 268 N. Y. 52, 60, 196 N. E. 740, 745 (1935). 
It may safely be said, in summarizing the present experience with authority legislation, that the "surrender of Home Rule" arguments, like the "delegation of power" claims, cut little or no judicial ice. If authority legislation is to be declared unconstitutional, the courts are more apt to find invalidity in the zone where restrictions imposed by constitutional debt limitations have been disregarded.

Constitutional Debt Limitations. The enabling acts of virtually every modern public authority either free the State and local government from any liability for the debt of the authority or achieve the same result by specifically denying the authority power to pledge the credit of the state or local government for its obligations. The patent purpose of this type of legislative restraint is to make certain that the bondholders shall, in the event of default, look only to the revenues and assets of the authority and shall not "call upon the public treasuries to contribute." 43 The authority concept, however, has been clrallenged in the courts as being violative of the intendment of the constitutional provisions with respect to debt limitations, since it "attempts by indirection to permit the bonded indebtedness of the $* * *$ City $* * *$ to exceed" its debt limit ${ }^{40}$ and as a "fiction designed to evade the constitutional limitation on indebtedness," tho theby striking down the "safeguard against municipal profligacy." 51

In the light of historical and economic considerations underlying the purposes of the constitutional restraints," the term "debt", it is clear, had reference to "an indebtedness to be met in the future by taxation." The distinction between a pledge of credit by a municipality and a pledge of revenues of a particular enterprise is fundamental. creates a charge or lien upon the city's general revenues, and, consequently, may properly be regarded as debt, while a pledge of revenues conveys a right to coerce payment only out of the special fund impounded by the pledge agreement so that recourse to the general tax fund is not available. $^{55}$ Hence, a pledge of enterprise revenues has no relation to the creation of a debt within the meaning of the constitutional limitations.

Perhaps the most comprehensive application of the special fund doctrine to authority financing is Department of Water \& Pozver of City

48. Tranter v. Allegheny County Authority, $316 \mathrm{~Pa} .65,82,173$ Atl. 289, 297 (1935).

49. Robertson v. Zimmermann, 268 N. Y. 52, 62, 196 N. E. 740, 743 (1935).

50. Tranter v. Allegheny County Authority, 316 Pa. 65, 173 Atl. 289 (1935).

51. Lesser v. Warren Borough, $237 \mathrm{~Pa} .501,513,85$ Atl. 839, 843 (1912).

52. See Williams \& Nehemkis, op. cit. supra, note 1, esp. pp. 177-181.

53. Bank for Savings v. Grace, 102 N. Y. $313,318,7$ N. E. 162 (1896). Cf. State v. City of Neosho, 203 MIo. 40, 82, 101 S. .W. 99, 109 (1907).

54. See Matter of Tierney v. Cohen, 268 N. Y. 464, 198 N. E. 225 (1935).

55. Cf. Fairbanks, Morse \& Co. v. City of Wagoner, 81 F. (2d) 209 (C. C. A. 10th, 1936). 
of Los Angeles v. Vroman. ${ }^{56}$ The Department is, essentially, an "independent body" or special corporation engaged in the distribution of light, heat and power for the City, and in the incurring of indebtedness it is not regarded as the City of Los Angeles nor "controlled by the constitutional provision" with respect to debt limitation. ${ }^{57}$ During the period from 1910 to 1926, general obligation bonds of the City of Los Angeles in the amount of $\$ 50,500,000$ were duly authorized for electrical works purposes. A power revenue fund was established, and in it were deposited the proceeds of the bonds issued and sold as well as all other revenues for the payment of the debt. In 1933, the Department sought to enter into a contract with the Reconstruction Finance Corporation for a loan of $\$ 22,800,000$ for the construction of certain transmission lines and facilities. The case came before the California Supreme Court on petition of the Department for a writ of mandate to compel Vroman, as secretary of the Board of Water \& Power Commissioners of the City, under whose jurisdiction the Department fell, to execute the agreement in behalf of the Department. The principal contention of the respondent was that the contract, if executed, would be illegal since a provision in the contract requiring repayment to the Reconstruction Finance Corporation out of the revenues of the existing electrical works of the City as well as from the revenues of the new transmission system proposed to be constructed would render the loan agreement outside the scope of the special fund doctrine to which the Court was committed, and thereby create an indebtedness within the purview of the constitutional prohibition. ${ }^{58}$ To this objection the court was unable to attach any "particular significance." Whatever importance the objection did present, the Court conceded, lay in the fact that the power revenue fund might prove to be inadequate. In that event the taxpayers would be called upon to pay taxes to meet the maturities on the general bonds of the City previously issued, a burden, the Court observed, which existed prior to the loan agreement and was not affected by it. The Court held the loan agreement, and the notes which were to be issued as evidence of the loan, not to be obligations of the City. ${ }^{59}$

56. 218 Cal. 206, 22 P. (2d) 698 (1933).

57. Id. at $219,22 \mathrm{P}$. (2d) at 704 ; $c f$. California Toll Bridge Authority v. Kelly, 218 Cal. 7, 14, 21 P. (2d) 425, 428 (1933).

58. Shelton v. City of Los Angeles, 205 Cal. 544, 275 Pac. 421 (1929); Garret v. Swanton, 216 Cal. 220, 13 P. (2d) 725 (1932). For the theoretical assumptions of this theory and its limitations, see Williams \& Nehemkis, op. cit. sutpra note 1, at 192-197; cf. Robertson v. Zimmermann, 268 N. Y. 52, 196 N. E. 740 (1935).

59. The California Supreme Court has handed down several other discursive opinions on this question. In In re California Toll Bridge Authority v. Wentworth, 212 Cal. 298, 298 Pac. 485 (1931) the statutory provision for the segregation of toll revenucs of the San Francisco-Oakland Bridge into a special fund to which the bondholders must look for payment was held not to create debt within the meaning of the constitutional 
Of utmost importance in this question of constitutional debt limitations are the precise terms of the security provisions. Of course, where the hypothecation of revenues is employed as a security device, the ultimate immunity of the taxpayer from liability for the authority's default is assured. But the placing of a mortgage, particularly on an existing system to pay for an improvenent thereto, is regarded as having a different effect. ${ }^{60}$. The incidence of foreclosure ${ }^{61}$ would, it is contended, tend to press the local government to turn to the tax coffers rather than permit the enterprise to pass into private hands at a foreclosure sale. This position, which has been adopted by some courts, ${ }^{62}$ is not without validity, especially where general mortgage bonds are issued to pay for an improvement to an existing system. Where, however, the so-called mortgage does not carry the right of foreclosure but merely provides for a receiver or trustee ${ }^{63}$ to operate the enterprise and collect revenues, it has been held that the debt of the enterprise is not subject to the general taxing power. ${ }^{64}$ This follows from the fact that the obligation is to all intent and purpose a special fund contract.

The problem of the taxpayer's ultimate liability could be greatly simplified by complete elimination of the mortgage instrument in authority financing. It offers no greater protection than is afforded by an indenture containing proper protective covenants or, for that matter, by an appropriate resolution of the authority itself. In preparing the indenture or resolution, however, the draftsman should take care to specify distinctly that the security extends only to the special revenue fund and that the exercise of the power of foreclosure or sale is precluded. ${ }^{65}$ For so long as the authority's property is not subjected to the hazards of a fore-

limitation. The same authority was involved in California Toll Bridge Authority v. Kelly, 218 Cal. 7, 21 P. (2d) 425 (1933), but here the situation was complicated by a state subsidy to the authority which the Reconstruction Finance Corporation had required before taking the authority's bond issue. The Court overruled the objection that the bonds were thus being transformed into general obligations of the state by the simple statement that "such transformation or transition [was] not apparent."

60. See, e.g., City of Joliet v. Alexander, 194 Ill. 457, 62 N. E. 861 (1902). A ciearcut decision by the New York Court of Appeals on the validity of a mortgage accompanying a pledge of revenues is not available. But see the Zimmermamn case, 268 N.Y. 52, 196 N.E. 740 (1935), discussed in Williams \& Nehemkis, of. cil. supro note 1, at 206.

61. Foreclosure upon municipalities is rare; there is, nevertheless, no legal obstacle to enforcement. Id. at 197, n. 94.

62. Id. at 198 , n. 95.

63. See Tranter v. Allegheny County Authority, $316 \mathrm{~Pa} .65,173$ Atl. 289 (1935); Clarke v. South Carolina Public Service Authority, 177 S. C. 427, 181 S. E. 481 (1935); see also Alabama State Bridge Corporation v. Smith, 217 Ala. 311, 116 So. 695, 693 (1928) ; cf. State ex rel. Loseke v. Fricke, 126 Neb. 736, 254 N. W. 409 (1934).

64. City of Bowling Green v. Kirby, 220 Ky. 839, 295 S. W. 1004 (1927) ; Banlihead v. Town of Sulligent, 155 So. 869 (Ala. 1934).

65. See generally 3 Jones, Mortanges (8th ed. 1928) $\$ \S 1600-01$. 
closure or sale, "the giving of a mortgage over property to be acquired from the proceeds of the bonds to be sold" will not "change the status of the bonds so as to make them debts *** within the constitutional inhibitions." ${ }^{66}$ An indenture without the incidence of a foreclosure or sale but with right of entry and operation should not be distressing to bondholders where the other security provisions afford adequate protection - as is true with the preponderance of present authority legislation. Certainly, in the case of any sizeable utility the right of foreclosure or sale is at best a dubious remedy since the possibility of a purchaser with available cash is remote. In the last analysis the bondholder's security depends on competent management and adequate earning power. If public management proves to be satisfactory, foreclosure is not necessary; on the other hand, if the management becomes "political" or proves to be incompetent, ousting of the management should provide adequate remedy. ${ }^{67}$

\section{REMEDIES OF BONDHOLDERS}

Enforcement of authority obligations secured primarily by special revenue funds is to be distinguished from the enforcement of municipal general bonds or special assessment bonds, for while the latter types of obligation afford holders remedies which have had the benefit of judicial sanction, ${ }^{68}$ the remedies of the holder of an authority revenue obligation are as yet untried. Experience with this type of public financing has been too recent to allow the crystallization of any body of remedial law. Since much of the recent volume of authority financing has been stimulated by depression factors, ${ }^{69}$ it will probably remain for the recurrence of the

66. Clarke v. South Carolina Public Service Authority, 177 S. C. 427,181 S. E. 481, 489 (1935).

67. This fact was appreciated in the proposed plan of unification of the rapid transit lines of the City of New York. The Plan permitted the trustees for the bondholders and the City of New York to invoke a change in the management of the proposed Board of Transit Control by a new body known as the "Board of Managers." A foreclosure sale and right to accelerate the principal of the bonds were expressly excluded. See Definitive Plan and. Unification Agreement Proposed for the Acguisition and Unification, Under Public OWNership and Control, of Rapid Transit Railsoads and Reiated Power Properties in the City of New York, June 22, 1936, at 118 et seq.

68. See generally, Fordham, Methods of Enforcing Satisfaction of Obligations of Public Corporations (1933) 33 CoL. L. REv. 28; Comment (1934) 43 YALE L. J. 924, at 962; Hinlmouse, Municipas Bonds (1936) 274 et seq.; Pershing, Revenue Bond Remedies (1937) 2 Legal Notes on Local Governament 262; Securities and Exchange Commission Report on tee Study and Investigation of ree Work, Activities, Personnez and Functions of Protective and Reorganization Commattees, Part IV, Comasityes for the Holders of Muntcipal and Quasi-Municipal Obligations (1936), at 16 et seq.

69. See, for the extent of financial aid by the Federal Government, Foley, Legal Problems Affecting the Non-Federal Phases of the Public Works Program (1935) Section of Munictpal Law, Amer. Bar Assoc., Summary of Proc., 29-30. 
nadir of the economic cycle to bring about the conditions requiring the exercise of remedial measures and their judicial definition.

Appointment of Receiver. The traditional right to the appointment of a receiver of the property and assets of a defaulting private corporation has never been the lot of the creditor of the public corporation. ${ }^{70}$ However, there would appear to be no real basis for the traditional antipathy of the courts to the appointment of a receiver for an authority. While it is true that the authority is an instrument of government, subject to the control of the legislature, and that its officers are engaged in the administration and discharge of public duties, the fact is that it is not created for the administration of civil government and it lacks all of the distinctly political attributes ${ }^{71}$ generally exercised by local government such as the police, licensing, taxation, legislative and judicial powers. The averseness of the courts to the appointment of a receiver in the absence of statutory authorization has consequently been overcome in most, if not all, existing authority legislation. ${ }^{72}$

Trusteeship. On the other hand, a question remains as to whether the courts will sanction the exercise of the rate-making prerogatives by a trustee or other representative of bondholders of a defaulting authority. In this case the ineritable contention will be that the default and entry by the trustee or creditors has altered the public nature of the enterprise; it will be urged that, while the covenant to maintain rates is valid with respect to the duly constituted directorate of the authority, it may not be enforced at the instance of private creditors "with arbitrary capacity to make their will prevail as law." 33 There has been no direct holding on this point, but the courts have indicated that the intervention of the trustee will be sanctioned. ${ }^{74}$

70. 2 Clark, Recervers (2d ed, 1929) §700; City of Enterprise v. State, 69 P. (2d) 953 (Ore. 1937).

71. See Foley, PWA and Revenue Financing of Public Enterprises (1935) SEcno:of Miunictpal Law, Ajrer. Bar Assoc., Suararary of Proc., 62.

72. Cf. Guardian Savings Co. v. Road District, 267 U.S. 1, 45 (1925); Yost צ. Dallas County, 236 U.S. 50 (1915). Iowa [IowA CoDe (1935) §12453] and Xlaryland [MD. Code ANN. (Bagby, 1924) art 75, \$ 141] have provided that creditors of municipalities might appeal to equity for the appointment of officers to carry out such acts as might be essential to satisfy a writ of mandamus. Cf. Lee County v. Rogers, 7 Wall. 181 (U.S. 1868). Certain jurisdictions have authorized appointments of receivers to collect taxes levied for the payment of irrigation and drainage district bonds in default. Legis. (1933) 46 HLARV. L. REv. 1317, 1320, n.24. In this connection it may be noted that the National Bankruptcy Act would appear to be available to authorities within the limited provisions of the recent amendment thereto. See Public L. No. 302, 75th Cons., 1st Sess. (1937).

73. Highland Farms Dairy, Inc, et al. v. Agnew et al., 80 Law Ed. 514, 518 (1937); cf. Yost v. Dallas County, 236 U. S. 50 (1915).

74. See cases cited n. 63, supra. 
Accounting. In jurisdictions which consider the income earned by the enterprise as a trust fund, the potentialities of equitable relief are extended: a bill in equity will lie to impress the special revenue fund with a trust and the bondholder may not only secure an accounting with respect thereto but control the application of the funds by a receiver. ${ }^{75}$

Mandamus and Injunction. It would seem that mandamus should lie for diversion of the revenue fund or failure to apply such funds in accordance with the priority of claims provided in the resolution or indenture. However, mandamus cannot be used if a statutory duty has not been violated $;^{76}$ and a statutory basis for the writ will not be available unless the statute expressly sets forth the order of priority or authorizes the use of the mandamus to assure collection of tolls as provided in the pledge agreement or resolution. ${ }^{77}$ Thus, if the statute merely empowers the authority to enter into a contract with bondholders with respect to the application of the fund, does the resolution of the authority or the indenture with respect thereto constitute the imposition of a statutory duty? The effort to determine a duty from implied powers may prove difficult. But whatever may be the doubt as to whether a writ of mandamus will lie, the bondholder is not helpless. Upon a proper showing against actual diversion or misapplication of revenues injunctive relief will be granted. ${ }^{78}$

\section{Taxability of Authority Bonds and Income}

Although the argument has been advanced ${ }^{70}$ that authority obligations do not warrant the immunity from taxation accorded to municipal and state obligations "since interference with borrowing for general gov. ernmental purposes is no longer a consideration," this contention ignores a major factor motivating the use of the authority device: the need on the part of many local governments for an additional credit base with which to finance necessary community improvements. The fact that the authority lacks recourse to the credit of the municipality or the state, or stands on its own feet supported by its own general credit, scarcely

75. See, e.g., Boynton v. Moffat Tunnel Improvement Dist., 57 F. (2d) 772 (C. C. A. 10th, 1932).

76. See State v. Smith, 335 Mo. 825, 74 S. W. (2d) 367 (1934).

77. Cf. Kelly v. Merry, 262 N. Y. 151, 186 N. E. 425 (1933). But cf. State ex rel. City of Vero Beach v. McConnell, 169 So. 628 (Fla. 1936).

78. George v. City of Asheville, N. C., 80 F. (2d) 50, 56, 57 (C. C. A. 4th, 1935); cf. Puget Sound Power and Light Co. v. City of Seattle, 271 Fed. 958, at 964 (W. D. Wash., 1921) ; Tyler County v. Town, 23 F. (2d) 371, 373 (C. C. A. 5th, 1928) ; Thompson v. Emmet Irr. Dist., 227 Fed. 560 (C. C. A. 9th, 1915); Vickrey v. City of Sioux City, 104 Fed. 164 (C. C. N. D., Iowa, 1900).

79. Miller, The Intergovernmental Problem in Taxation of Officers and Securities (1936) 2 Legal Notes on Local Government 3, 7. 
eliminates it as a vital function of contemporary local governmental borrowing. Recent experience has increasingly demonstrated that when the margin of borrowing permitted to the States and municipalities under the constitution is absorbed, the authority becomes the only available credit base with which local government is able to finance improvement projects. This fact has apparently been recognized by the Bureau of Internal Revenue, for recent rulings have exempted authority bonds from both the stamp ${ }^{80}$ and income taxes. ${ }^{81}$.

While the instances in which income accrues directly to a state or municipality from authority operations are relatively infrequent, ${ }^{82}$ the Bureau has not yet had occasion to pass on the question of taxability of income while in the coffers of the authority. Determination of the problem should present no serious difficulties. Section 116 (d) of the current Treasury regulations ${ }^{83}$ provides that "income derived from any

80. Opinion dated February 27, 1937, to Messrs. Hawkins, Delafield \& Longfellow, New York City, with respect to Marine Parkway. Triborough Bridge Authority bonds have been held not subject to stamp tax in Communication to Chairman of Authority, dated Feb. 27, 1937.

81. Communication to Messrs. Hawkins, Delafield \& Longfellow, New York City. In Article 22(b) (4)-1 of Treasury Regulation 86 there had been exempted from income tases the interest upon obligations of a State or any political subdivision thereof as well as upon "obligations issued by or on behalf of the State or a duly organized political subdivision acting by constituted authorities empowered to issue such obligations." For the purpose of the exemption "political subdivision" was made to include "special assessment districts \#\# such as road, water, sewer, gas, light, reclamation, drainage, irrigation, levee, school, harbor, port improvement, and similar districts and divisions." Plainly, revenue bonds issued by an authority are issued on behalf of a state or a political subdivision thereof. It may be presumed that, in carrying over the identical definition in Treasury Regulation 94, the Commissioner was not unaware that special assessment districts are no longer the exclusive agencies for effecting municipal and state improvements; and that many of the activities enumerated in the definition as the function of the assessment district are now performed by another varicty of public corporation, the authority. See 3 Finawcial Reporter 84 (1936); Wall St. Journal, Feb. 4 , 1937, p. 11, col. 2; cf. United States v. King County, Wash., 281 Fed. 685, 690 (C. C. A. 9th, 1922).

82. Income would accrue directly to a municipality from the operations of an authority where the municipality, for the purpose of achieving unified operation and management of utility properties, transferred such properties to a newly created authority for operation jointly with new property to be acquired from the proceeds of a bond issue. Under a lease arrangement the Authority might be required to pay a rental to the municipality for such properties. A practical illustration may be found in the plan proposed for the acquisition and unification of the rapid transit railroads in the City of New York, which contemplated that the rapid transit lines and the related power properties to be acquired by the City of New York should be leased to an Authority to be known as the Board of Transit Control. See Definitrve Plas akn Usification Agreentent Proposed for the Acquisition and Unification, Under Pumic Ownershit and Control, of Rapid Transit Ratiroads and Related Power ProzerTIES IN THE CITY OF NEW YORK (1936), at 146.

83. See U. S. Treas. Reg. 94 at p. 270. 
public utility or the exercise of any governmental function" and accruing to any State or political subdivision thereof shall be exempt from taxation. Regardless of the meaning which may be imputed to the language of the section, it is not a strain upon common sense to assume that there is a real distinction between income received directly by a corporation or an individual, on the one hand, and income received by a corporation or individual in the first instance, but which ultimately will be diverted to a state or municipality, on the other hand. The Bureau's position is stated in a General Counsel's Memorandum:

"Not only has the Bureau failed to tax the income of any State or municipality but it has throughout this period of 22 years made no effort to obtain income returns from States or municipalities, or to determine by any other means whether any State or municipality has had income of this nature. This persistent nonenforcement of the tax against States may be reasonably explained only as indicating a tacit construction by the Bureau in accordance with the interpretation which has just been suggested." 84

Further indication of the Bureau's attitude on this question appears from its interpretations involving questions concerning the taxability of the income of employees of a city or state engaged in carrying on functions which the Bureau characterizes as proprietary, i.e., non-governmental. Although it has asserted that such employees could not escape from a Federal income tax, it has never attempted to tax the income derived by the States and municipalities from such activities. ${ }^{85}$

The trend of the current interpretations by the Bureau leads to the conclusion that Section 116(d) exempts income derived by a corporation from the performance of a public or governmental function provided that the ultimate recipient of such income is to be the State or a political subdivision, ${ }^{86}$ and this conclusion is in no wise affected by the purely formal requirement that the corporation receiving such income in the first instance must file a return. Thus construed, the Bureau's rulings are entirely consistent with Congressional intent that income received by the States or municipalities irrespective of its source shall not be subject to federal tax. ${ }^{87}$

84. On construction of this seetion compare General Counsel's Memorandum 14407 (G. C. M. 14407, xiv-1 C. B. 103) with Griswold, Income Taxes of State Liquor Monopolies (1936) 22 A. B. A. J. 619, 621.

85. See e.g., S. M. 2232, C. B. III-2, 83 (cafeterias in public schools) ; I. T. 2357, C. B. VI-1, 52 (county hospitals). See also Wood v. Commissioner, 29 B. T. A. 919 (1934) ; Jamestown \& Newport Ferry Co. v. Commissioner, 41 F. (2d) 920 (C. C. A. 1st, 1930).

86. This is not true, however, in the bridge cases where the tax, if paid, is refunded. U. S. Treas. Reg. $94, \S 116$ (e).

87. To regard the income of an authority as "profit" is to mistake the authority's "personality". As was said by Mr. Justice Holmes in another context, but pertinent to 
Some dicta in Helvering $v$. Powers ${ }^{88}$ have occasioned misgivings to those who regard the authority as a proper legal device for avoidance of onerous constitutional debt restrictions. But it appears that the decision injects no new element into the traditional body of tax law. In holding as taxable income the salary of a trustee appointed by the Commonwealth of Massachusetts to operate, for a limited period of time, a private street railroad company and its properties, the Court in no wise deviated from the settled judicial pattern of sanctioning a tax imposed by either of the dual governments upon the other provided such tax did not bear directly upon an exercise of the sovereign power. The Commonwealth was attempting to rehabilitate by State subsidy a private corporation in order to enable it to carry on street railway operations; it was not substituting public ownership for private operation and ownership. The railway remained the property of the company, a private corporation, and was operated for private profit. $^{83}$ Plainly, in talking over the management and operation of a private company for a period of ten years, the State could not change the fundamental nature of the private business theretofore conducted by the company. Such apparently was the import of the Chief Justice's declaration that "the State cannot withdraw sources of revenue from the Federal taxing power by engaging in businesses which constitute a departure from usual governmental functions and to which, by reason of their nature, the Federal taxing power would normally extend." 90 With this in mind, the further declaration of the opinion, "the method which the State may adopt in organizing such activity cannot be regarded as determinative," ceases to be a caveat against authority undertakings.

\section{The Authority in Metropolitan Areas}

The pervasive modern public utility systems for the supply of light, heat, power, water, transportation and communication have inundated the arena of political government with economic zones which threaten to render obsolete the traditional concepts of territorial government. These economic zones are being administered in considerable part by

the instant discussion, "This is not like the case of a corporation having its own purposes as well as those of the United States and interested in profit on its own account. The incorporation and formal erection of a new personality was only for the convenience of the United States to carry out its ends." Clallam County v. United States, 263 U. S. 341, 345 (1923). See also, People ex rel. Rogers v. Graves, 57 Sup. Ct. 269, 272 (1936) ; Commissioner v. Ten Eyck, 76 F. (2d) 515, 519 (C. C. A. 2d, 1935).

88. 293 U. S. 214 (1934).

89. Government Counsel conceded this fact in his brief. It was also admitted that the compensation of the Trustees was paid by the railroad company.

90. 293 U. S. 214 , at 225 (1934). 
the public authority. ${ }^{91}$ The significance of the authority device as a means for permitting the functioning of economic government within the framework of local governments is illustrated by the situation in metropolitan New York. Although the political periphery of the government of the city embraces only the five boroughs which cover slightly more than 300 square miles, its sphere of economic influence extends to a region of some 5,528 square miles. ${ }^{22}$ And operating in this latter area is a group of authorities performing a variety of functions, some of which cannot be carried on efficiently, and some not at all, by a local governmental unit. ${ }^{03}$

The advantage flowing from the subordination of artificial political boundaries to more pertinent economic lines is, however, often counteracted by the incorporation of a multitude of authorities within the same area for a variety of purposes, some of which are overlapping. This proliferation tends to create a system of government by uncoordinated authorities, which, as a result of complex and unique functional differences, renders ultimate public control ineffectual. It is true, of course, that each of the individual authorities performs a specialized function and in a narrow sense represents planned activity. But of the public corporations which have been considered, The Port of New York Authority alone has succeeded in carrying out a scientifically determined program of regional planning. Under unified management and control the Port Authority has provided an economically adequate solution to the harbor, bridge, tunnel, railroad, and freight distribution problems of the New York metropolitan area. In the sphere of planning the Port Authority has served a two-fold purpose: it has provided a mechanism for consultation among various local governments for the development of integrated programs of related activities, and in the interstate sector of its operations it has projected blueprints for the development of broadgauge harbor, port, communication and traffic facilities. In short, through a functional adaptation of the public corporation The Port of New York

91. Under Congressional legislation now pending the scope of the authority is to. be extended vastly. See H. R. Doc. No. 261, 75th Cong., 1st Sess. (1937) at 3; N. Y. Times, June 4, 1937, p. 12, col. 3 .

92. This is, broadly speaking, the metropolitan area covered by the planning surveys of the Regional Plan Association, Inc., New York, a non-governmental body which has developed comprehensive plans for the region. See, 1 Regronal PLAN of* New York and Its Environs, the Graphic Regtonal Plan (1929) at 127.

93. These authorities are as follows: The Port of New York Authority, the New York City Tunnel Authority, the Triborough Bridge Authority, the Marine Parkway Authority, the Henry Hudson Parkway Authority, the Bethpage Park Authority, the Pelham-Port Chester Parkway Authority, the Jones Beach State Park Authority, the Rockland Westchester Hudson River Crossing Authority, the New York City Housing Authority. Although operating within this metropolitan region, the Delaware River Joint Commission does not, of course, impinge upon the government of the City of New York. It is, nevertheless, illustrative of the point vis-a-vis Philadelphia and Camden. 
Authority is effectively bridging the hiatus which exists between economic and political spheres of government.

In marked contrast to the high degree of integration evidenced by The Port of New York Authority, the haphazard establishment of separate authorities in response to immediate political or social exigencies and in many instances having no direct relation to a farsighted or comprehensive program of regional planning, results only in multiplying the existing confusion of metropolitan government and affecting adversely the marketability of security obligations by creating additional layers of government with concomitant administrative problems. The marketing difficulty is caused by the fact that the authority is largely dependent upon its own peculiar market, which is of a limited institutional character ${ }^{94}$ for the distribution and refunding of its securities. The sporadic flotation of authority issues will inevitably result in a premature saturation of such market with its attendant reaction upon the necessary financing of state and municipal improvements.

Furthermore, where several authorities performing similar or identical services are engaged in draining revenues within the same area, the result of such uneconomic competition is apt seriously to affect the ability of particular enterprises so situated to earn sufficient revenues to support their individual debt. For this reason, if for no other, authorities performing similar functions within the same geographical area would benefit by a grouping of facilities under a single management and by a consolidation of their respective debt, so far as practicable. The resultant elimination of specific claims on the revenues of individual authority undertakings in favor of a single charge on group facilities would seem to be highly desirable. In this respect experience has made it increasingly evident that neither fiscal, accounting, management nor operating factors indicate any compelling reasons for adherence to the practice of financing improvement projects as isolated authority undertakings. The principles of regional planning dictate the contrary: $:^{95}$ the record of performance

94. The authority bond, it should be noted, lacks the wide distribution and diversification of ownership and holdings characteristic of the industrial or utility security. Authority securities, when not held by agencies of the Federal government, are predominantly confined to institutional investment portfolios. Thus, for example, the largest blocks of The Pork of New York Authority 45 are held by 21 insurance companies, the $4^{\mathrm{T}} / 4 s$ by 35 insurance companies, the $4^{1 / 2 s}$ by 36 insurance companies. Banlis, benevolent associations and pension retirement systems make up the remainder of large institutional holders. See Keane, Institumonal Holdings of Securities (1935-36) 28342885. To a considerable extent, therefore, the distribution of the authority security is dependent upon the receptivity of institutional holders. And as institutions usually have a fixed policy governing the amount of any given type of security which will be held, portfolios already bulging with authority securities will obviously act as a deterrent to new underwriting activities for such securities.

95. See, for example, the methods outlined in Rogroxal PLAN asid Its Emrifors, op. cit. supra note 92, at 134. The literature on the subject of regional planning is 
of The Port of New York Authority is persuasive evidence that unified management of and control over group facilities with a general obligation possessing a claim upon all such facilities is the more desirable financial policy. ${ }^{96}$ Some progress toward this objective has already been made. In metropolitan New York, the Regional Plan Association, an unofficial planning body, has achieved signal results. ${ }^{27}$ Moreover, the City of New York's new charter provides for a city planning commission as a department of the City government; if endowed with a competent and intelligent personnel, it may exercise a significant influence over future authority development within the city. ${ }^{98}$ The work of both these groups might be supplemented to advantage by an "Authority Planning Council" consisting of the Chairmen of New York State's thirty odd authorities. Such a council could pool statistical and engineering data, and, by cooperating with the Regional Plan Association and the local governments, could readily become the planning body of the State and region - certainly in respect to future authority development. ${ }^{90}$

The authority mechanism as employed in metropolitan and regional planning presents a further problem. Its financial structure has been predicated upon earning power. In practice, this means that the successful operation of an authority is dependent upon its ability to meet operating expenses, maintenance charges and interest and to build up an adequate surplus for sinking and reserve funds. Of course, if the test of economic self-sufficiency is to be applied as a factor of conclusive importance, the use of the public authority as a device for rendering various services in the traditional fields of public service would not, by hypothesis, be justifiable.

voluminous. For an excellent bibliography, see Regional Planning, 13 Encxc. Soc. Sctences 205 (1934).

96. In 1931, The Port of New York Authority adopted a policy designed to unify the construction, maintenance, operation and control of its existing facilities and such as were to be subsequently authorized to the end that the aggregate tolls and revenues derived therefrom would be applied, so far as practicable, to the facilities as a group. Accordingly, in 1935 (when market conditions had become favorable) all of the then outstanding bond issues were refunded and consolidated into one type of general obligation possessing a claim upon the unified facilities. See, The PORT of NEW York AUTHORYTY, Fifteenth Annual Report (1935).

97. The plans of the Association are embodied in a survey consisting of ten volumes: Regional SuRvey of NEW York aNd Its Envrons (1922-1931). They have been carried forward by the Regional Plan Association in The GrapHic Regronal PLAN (1929) and The Bunding of the CiTy (1931).

98. New York City Charter, c. $8, \S \S 191-202$. The charter becomes effective on January $1,1938$.

99. See, generally, Schmidt, Comntry Plaming in the Ruhr District, XIV Jourarar of the Town Planning Institute (1927-28) 47-52; Fuchs, Regional Agencies for Metropolitan Areas (1936) 22 WASH. UnIv. L. REv. 64 passim. 
It is, therefore, imperative that municipal and state officers should give increasingly serious consideration to the problem of differentiating between public services which can be performed properly by an authority, i.e., self-supporting enterprises, and public services which are not economically self-supporting. In the latter case, although the public corporation may still be utilized for administrative convenience, it must be frankly recognized that its financial foundation must rest primarily upon some form of taxation or special assessments. Not only may it be good public finance to meet the cost of certain types of utility undertakings by general municipal obligations, but it may be to the positive advantage of the taxpayer to do so. The enormous appreciation in real estate values in New York City would not have been possible in the absence of rapid transit at a five cent fare. In this instance, the subsidizing of a public utility has been distinctly advantageous to the taxpayer qua real estate owner. However, where it is proposed to utilize the authority for the operation of a public utility undertaking, and the ultimate economic independence of the enterprise cannot be demonstrated, a mixed undertaking may be the better financial policy; that is to say, additional support should be given to the income derived from tolls or revenues by taxation or special assessments or assessment quotas contributed by the towns and cities within the area served by such authority.

Since the type of authority with which this discussion has been primarily concerned is designed to amortize its debt solely from revenues or tolls without recourse to taxation, continued neglect by public officials in observing this distinction in the initial establishment of authorities may unwittingly have the effect of accelerating their insolvency. Although the State and municipal governments generally are relieved of liability in the event of an authority's default, the occurrence of such defaults would undoubtedly have a marked effect upon the credit standing of the local governments concerned; and if such defaults were, perchance, widespread, the ensuing legislative prophylaxis - if the history of constitutional debt limitations has any significance - would unquestionably impair the usefulness of the authority device. 